Ekonomis: Journal of Economics and Business, 5(1), Maret 2021, 253-259

Publisher: Lembaga Penelitian dan Pengabdian kepada Masyarakat Universitas Batanghari Jambi

Address: Jl. Slamet Ryadi, Broni-Jambi Kodepos: 36122

Website: http://ekonomis.unbari.ac.id, email: ekonomis.unbari@gmail.com

ISSN 2597-8829 (Online), DOI 10.33087/ekonomis.v5i1.293

\title{
Analisis Faktor-Faktor Yang Mempengaruhi Kinerja Sistem Informasi Akuntansi (Studi Empiris Pada Boys Bakery and Cake Sukoharjo)
}

\author{
Annisa' Amanatyas Wahyudi Putri*, Endang Masitoh, Purnama Siddi \\ Program Studi Akuntansi, Fakultas Ekonomi, Universitas Islam Batik Surakarta \\ "Correspondence email: sasaputriwp@gmail.com
}

\begin{abstract}
Abstrak. Penelitian ini bertujuan Menguji dan menganalisis pengaruh keterlibatan pemakai, kemampuan teknik personal, dukungan manajemen puncak (Struktur organisasi), formalisasi pengembangan sistem dan program pelatihan dan pendidikan terhadap kinerja sistem informasi akuntansi. Sumber data adalah data primer berupa hasil jawaban angke dan data sekunder berupa gambaran umum tentang Boys Bakery and Cake. Metode yang dipakai dalam penelitian ini adalah uji asumsi klasik dan analisis regresi linier berganda dengan bantuan program SPSS versi 26.Populasi dalam penelitian ini sebanyak 74 orang. Sampel dipilih dari metode purposive sampling sebanyak 55 orang dari beberapa bagian dan cabang. Hasil dari penelitian ini menunjukan bahwa keterlibatan pemakai dan program pelatihan berpengaruh terhadap kinerja Sistem Informasi Akuntansi sedangkan kemampuan teknik personal, dukungan manajemen puncak (Struktur organisasi), formalisasi pengembangan sistem tidak berpengaruh terhadap kinerja Sistem Informasi Akuntansi
\end{abstract}

Kata Kunci: Sistem Informasi Akunansi; keterlibatan pemakai; kemampuan teknik personal; dukungan manajemen puncak (Struktur organisasi); formalisasi pengembangan sistem dan program pelatihan

\begin{abstract}
This study aims to examine and analyze the effect of user involvement, personal technical skills, top management support (organizational structure), formalization of system development and training and education programs on the performance of accounting information systems. Sources of data are primary data in the form of answers to angke and secondary data in the form of an overview of Boys Bakery and Cake. The method used in this study is the classical assumption test and multiple linear regression analysis with the help of the SPSS version 26 program. The population in this study was 74 people. The sample was selected from the purposive sampling method as many as 55 people from several sections and branches. The results of this study indicate that user involvement and training programs have an effect on the performance of the Accounting Information System while personal engineering skills, top management support (organizational structure), formalization of system development have no effect on the performance of the Accounting Information System.
\end{abstract}

Keywords: Accounting Information Systems; user involvement; personal technical skills; top management support (organizational structure); formalization of systems development and training programs

\section{PENDAHULUAN}

Saat ini perkembangan sistem informasi dan teknologi begitu pesat, sehingga dengan perkembangan sistem informasi sangat mempengaruhi kinerja perusahaan secara keseluruhan. Informasi merupakan output dari suatu sistem informasi. Guna memperoleh informasi, maka dibutuhkan data karena merupakan input dari suatu sistem. Data diperoleh dari transaksi-transaksi atau kegiatan yang terjadi dalam perusahaan.Sistem informasi semakin diperlukan, baik untuk membantu manajemen dalam menjalankan fungsinya maupun untuk kelangsungan perusahaan itu sendiri. Persaingan bisnis yang ketat dengan perusahaan lain untuk memperoleh kepercayaan masyarakat, mengharuskan perusahaan untuk selalu meningkatkan kinerjanya terutama pada kinerja sistem informasi akuntansi. Menurut Mulyadi (2016) pengertian sistem informasiakuntansi adalah organisasi formulir, catatan dan laporan yang dikoordinasi sedemikian rupa untuk menyediakan informasi keuangan yang dibutuhkan oleh manajemen guna memudahkan pengelolaan perusahaan.

Efektifitas kinerja dari sistem informasi akuntansi yang diterapkan dapat dilihat dari segi pemakai sistem informasi akuntansi itu sendiri.Selanjutnya dapat dikatakan baahwa sebuah sistem informasi itu berhasil apabila didukung oleh beberapa faktor. Menurut Soegiharto dan Tjai Fung Jen (Almilia and Briliantien, 2007) ada beberapa faktor yang dapat mempengaruhi kinerja sistem informasi akuntansi, antara lain: keterlibatan pemakai dalam pengembangan sistem, kemampuan teknik personal, dukungan manajemen puncak, formalisasi pengembangan sistem informasi dan program pelatihan serta pendidikan pemakai sistem informasi akuntansi.Boys Bakery and Cake Sukoharjo salah satu perusahaan yang dalam praktek kesehariannya juga menggunakan sistem informasi akuntansi meskipun masih sangat sederhana hal ini dikarenakan Boys Bakery and Cake Sukoharjo merupakan perusahaan yang tergolong pada UMKM (Usaha Mikro Kecil dan Menengah). Saat ini ditengah persaingan bisnis di online begitu semarak dan dilanda pandemi Covid-19 maka penulis ingin mengetahui meneliti sejauh mana faktor-faktor yang 
mempengaruhi kinerja karyawan dengan sistem informasi akuntansi.

Tujuan penelitian ini adalah menganalisis Faktor-faktor yang mempengaruhi kinerja sistem informasi akuntansi (Studi Empiris Pada Boys Bakery and Cake Sukoharjo)

\section{Definisi Operasional dan Variabel Penelitian Sistem Informasi Akuntansi}

Azhar Susanto (2013) menyatakan definisi sistem informasi akuntansi adalah: Sistem informasi akuntansi dapat didefinisikan sebagai kumpulan (integrasi) dari sub-sub sistem/ komponen baik fisik maupun non fisik yang saling berhubungan dan bekerja sama satu sama lain secara harmonis untuk mengolah data transaksi yang berkaitan dengan masalah keuangan menjadi informasi keuangan. Keterlibatan mempengaruhi kriteria kunci seperti kualitas sistem, kepuasan pengguna dan penggunaaan sistem oleh Iven dan Olson, Bruver serta Hirschelm (Komara, 2005).

\section{Kemampuan teknik personal}

Pemakai sistem informasi yang memiliki kemampuan yang diperoleh dari pendidikan dan pengalaman akan meningkatkan kepuasan dalam menggunakan Sistem Informasi Akuntansi dan akan terus menggunakannya dalam membantu menyelesaikan pekerjaannya karena pemakai memiliki pengetahuan dan kemampuannya yang memadai.

\section{Dukungan manajemen puncak}

Manajemen puncak atau disebut Top Management sebagai pihak yang bertanggung jawab atas keberhasilan semua kegiatan yang berhubungan dengan sistem informasi yang akan menyediakan pedoman bagi kegiatan informasi agar pengguna sistem tidak mendapatkan kesulitan dalam mengoperasikan sistem tersebut.

\section{Formalisasi pengembangan sistem}

Formalisasi pengembangan sistem memiliki hubungan dengan keberhasilan sistem informasi.Hal in juga dijelaskan dari penelitian yang dilakukan Neal dan Reader yang dikutip oleh (Rusdi dan Megawati, 2011) menunjukkan hubungan positif antara riset operasional atau keberhasilan suatu manajemen sains dan formalisasi dengan prosedur riset operasi atau manajemen sains.

\section{Pelatihan dan pendidikan pemakai}

Pelatihan dan pendidikan, pengguna bisa mendapatkan kemampuan untuk mengidentifikasi persyaratan informasi mereka dan kesungguhan serta keterbatasan sistem informasi dan kemampuan ini dapat mengarah pada peningkatan kinerja menurut Montazemi (Komara, 2005).

\section{METODE}

Penelitian ini menggunakan jenis penelitian kuantitatif dengan pendekatan deskriptif. Metode penelitian kuantitatif merupakan salah satu jenis penelitian yang spesifikasinya adalah sistematis, terencana dan terstruktur dengan jelas sejak awal hingga pembuatan desain penelitiannya. Sugiyono (2013), metode penelitian kuantitatif dapat diartikan sebagai metode penelitian yang berlandaskan pada filsafat positivisme, digunakan untuk meneliti pada populasi atau sampel tertentu, teknik pengembilan pada umumnya diilakukan secara random, pengumpulan data menggunakan instrumen penelitian, analisis data bersifat kuantitatif/statistik dengan tujuan untuk menguji hipotesis yang telah ditetapkan. Teknik pengumpulan data dilakukan dengan angket untuk memperoleh data tentang Faktorfaktor Sistem Informasi Akuntansi dan wawancara untuk memperoleh informasi tentang gambaran umum perusahaan.Sumber data yang digunakan dalam penelitian ini adalah: Data primer adalah jawaban responden dari kuesioner yang disebar dan Data Sekunder adalah data jumlah karyawan dan penjelasan atau gambaran umum tentang perusahaan.

\section{Uji Asumsi Klasik \\ Uji Normalitas}

Menurut Ghozali (2016) uji normalitas memiliki tujuan untuk menguji apakah pada suatu model regresi suatu variable dependepen ataupun keduanya terdistribusi normal atau tidak.Dalam penelitian ini, uji normalitas menggunakan uji Kolmogorov-Smirnov (K-S).

\section{Uji Multikolinieritas}

Menurut Ghozali (2016) uji multikolinieritas memiliki tujuan untuk menguji apakah dalam suatu model regresi terdapat kolinearitas antar variabel independen (bebas).Uji ini dilakukan dengan melihat nilai VIF dan tolerance pada hasil regresi. Apabila nilai VIF kurang dari 10 dan tolerance lebih dari 0,1 maka dinyatakan tidak terjadi multikolinieritas. 
Annisa' Amanatyas Wahyudi Putri*, Endang Masitoh dan Purnama Siddi, Analisis Faktor-Faktor Yang Mempengaruhi Kinerja Sistem Informasi Akuntansi (Studi Empiris Pada Boys Bakery and Cake Sukoharjo)

\section{Uji Autokorelasi}

Menurut Ghozali (2016) uji ini bisa terjadi karena observasi yang berurutan sepanjang waktu yang berkaitan satu sama lainnya.Untuk model regresi yang baik adalah pada model regresi yang bebas dari autokorelasi. Untuk mendeteksi terdapat atau tidaknya autokorelasi adalah dengan melakukan uji Run-Test.

\section{Uji Heteroskedastisitas}

Menurut Ghozali (2016) uji heteroskedastisitas memiliki tujuan untuk menguji apakah dalam regresi tersebut terjadi kesalahan variance dari pengamatan satu ke pengamatan lainnya, apabila variance dari residual satu pengamatan ke pengamatan lainnya tidak berubah, maka dinamakan homoskedastisitas dan apabila berbeda dinamakan heteroskedastisitas. Regresi bisa disebut baik apabila nilai signifikansi $>0,05$ maka dapat dikatakan tidak terjadi heteroskedastisitas. Dalam pengujian ini peneliti menggunakan metode glejser.

\section{Model Analisis Data Penelitian}

Adapun model analisis data penelitian adalah Regresi Linear Berganda.Penggunaan teknik analisis regresi linear berganda untuk penelitian ini diolah dengan menggunakan bantuan program SPSS 26. Berikut gambaran persamaan regresi linear berganda pada penelitian ini:

$Y=a+b 1 . x 1+b 2 . x 2+b 3 . x 3+b 4 . x 4+b 5 . x 5+e$

Keterangan: $\mathrm{Y}=$ Kinerja SIA; $\mathrm{a}=$ konstanta (tetap); b1, b2, b3, b4, b5 = koefesien regresi; $\mathrm{x} 1=$ keterlibatan pengguna dalam pengembangan SIA; $\mathrm{x} 2=$ program pelatihan dan pendidikan; $\mathrm{x} 3=$ dukungan manajemen puncak; $\mathrm{x} 4=$ formalisasi pengembangan SIA; x5 = kemampuan teknik personal; e = kesalahan prediksi (error)

\section{Uji Koefisien Determinasi Adjusted $\left(R^{2}\right)$}

Menurut Ghozali (2016) koefisien determinasi bertujuan untuk mengukur seberapa jauh kemampuan model dalam menerangkan variable-variabel dependen.

\section{Pengujian Hipotesis secara Simultan (Uji F)}

Menurut Ghozali (2016) pengujian ini digunakan untuk mengetahui apakah variable bebas secara bersama-sama berpengaruh terhadap variable dependen. Secara simultan adalah dengan cara membandingkan $F_{\text {hitung }}$ dengan nilai $F_{\text {tabel }}$ sesuai dengan tingkat signifikansi yang digunakan yaitu 5 persen.

\section{Pengujian Hipotesis secara Parsial (Uji t)}

Menurut Ghozali (2016) uji hipotesis digunakan untuk melihat pengaruh masing-masing variable independen secara parsial terhadap variable dependen.Uji ini digunakan untuk mengetahui apakah risiko kredit, suku bunga dan likuiditas berpengaruh atau tidak terhadap profitabilitas bank.

\section{Hasil}

\section{Uji Normalitas}

Tabel 1.

Uji Normalitas Data dengan Kolmogorov-Smirnov

\begin{tabular}{lrr}
\hline & & Unstandardized Residual \\
\hline $\mathrm{N}$ & & 55 \\
Normal Parameters & \\
& Mean & .0000000 \\
Most Extreme Differences & Std. Deviation & 1.49266195 \\
& Absolute & .088 \\
Test Statistic & Positive & .070 \\
Asymp. Sig. (2-tailed) & Negative & -.088 \\
\hline
\end{tabular}

Sumber: data olahan

Berdasarkan tabel 1 data terdistribusi normal dengan nilai significant 0,088>0,05 pada uji normalitas Kolmogorov smirnov. 
Annisa' Amanatyas Wahyudi Putri*, Endang Masitoh dan Purnama Siddi, Analisis Faktor-Faktor Yang Mempengaruhi Kinerja Sistem Informasi Akuntansi (Studi Empiris Pada Boys Bakery and Cake Sukoharjo)

\section{Uji Multikolinieritas}

Tabel 2

Uji Multikolinearitas terhadap Model regresi

\begin{tabular}{|c|c|c|}
\hline \multirow{2}{*}{ Model } & Collinearity Statistics & \multirow{2}{*}{ Keterangan } \\
\hline & Tolerance & \\
\hline $\bar{X} 1$ & .939 & 1.065 Tidak terjadi multikolinearitas \\
\hline $\mathrm{X} 2$ & .802 & 1.248 Tidak terjadi multikolinearitas \\
\hline X3 & .945 & 1.058 Tidak terjadi multikolinearitas \\
\hline $\mathrm{X} 4$ & .887 & 1.128 Tidak terjadi multikolinearitas \\
\hline $\mathrm{X} 5$ & .762 & 1.313 Tidak terjadi multikolinearitas \\
\hline
\end{tabular}

Sumber: data olahan

Berdasarkan tabel 2 diketahui bahwa hasil VIF $<10$ dan mempunyai nilai tolerance $>0,10$. Hal ini menunjukkan bahwa semua variabel yang digunakan tidak terjadi multikolinieritas.

\section{Uji Autokorelasi}

Tabel.3

Uji Autokorelasi

\begin{tabular}{rrrrrr}
\hline Model & R & R Square & Adjusted R Square & Std. Error of the Estimate & Durbin-Watson \\
\hline 1 &, $532^{\mathrm{a}}$ &, 283 &, 209 & 1,56697 & 1,695 \\
\hline
\end{tabular}

Sumber: data olahan

Berdasarkan hasil tabel 3 diatas dapat diketahui pengujian autokorelasi terhadap nilai residual diperoleh nilai 0,209>0,05. Hal ini menjelaskan bahwa data residual hasil estimasi menunjukkan tidak terjadi autokorelasi.

\section{Uji Heteroskedastisitas}

Tabel 4

Uji Glejser-Heteroskedastisitas

\begin{tabular}{lll}
\hline Model & Sig. & Keterangan \\
\hline X1 & .657 & Tidak terjadi heterokedastisitas \\
X3 & .793 & Tidak terjadi heterokedastisitas \\
X4 & .260 & Tidak terjadi heterokedastisitas \\
X5 & .953 & Tidak terjadi heterokedastisitas \\
\hline
\end{tabular}

Sumber: data olahan

Berdasarkan hasil tabel 4 diatas dapat diketahui bahwa masing-masing nilai signifikansi semua variabel independent $>0,05$. Hal ini menunjukkan bahwa variabel - variabel tersebut tidak terjadi heteroskedastisitas.

\section{Analisis regresi linear berganda}

Tabel 5

Persamaan Regresi

\begin{tabular}{|c|c|c|c|c|c|c|}
\hline & \multirow{2}{*}{ Model } & \multicolumn{2}{|c|}{ Unstandardized Coefficients } & \multirow{2}{*}{$\begin{array}{c}\text { Standardized Coefficients } \\
\text { Beta }\end{array}$} & \multirow{2}{*}{$\mathrm{t}$} & \multirow{2}{*}{ Sig. } \\
\hline & & $\mathrm{B}$ & Std. Error & & & \\
\hline \multirow{6}{*}{1} & Const & 9.610 & 3.455 & & 2.781 & .008 \\
\hline & $\mathrm{X} 1$ & .139 & .059 & .296 & 2.371 & .022 \\
\hline & $\mathrm{X} 2$ & .065 & .102 & .086 & .638 & .527 \\
\hline & $\mathrm{X} 3$ & .031 & .097 & .040 & .317 & .752 \\
\hline & $\mathrm{X} 4$ & .075 & .115 & .083 & .648 & .520 \\
\hline & $\mathrm{X} 5$ & .335 & .140 & .331 & 2.384 & .021 \\
\hline
\end{tabular}

Sumber: data olahan

Tabel 5 diatas dapat disusun persamaan regresi sebagai berikut :

$Y=9,610+0,139 X_{1}+0,065 X_{2}+0,031 X_{3}+0,075 X_{4}+0,335 X_{5}$ 
Annisa' Amanatyas Wahyudi Putri*, Endang Masitoh dan Purnama Siddi, Analisis Faktor-Faktor Yang Mempengaruhi Kinerja Sistem Informasi Akuntansi (Studi Empiris Pada Boys Bakery and Cake Sukoharjo)

\section{Koefisien Determinasi $\left(R^{2}\right)$}

Tabel 6

Koefisien Determinasi $\left(\mathrm{R}^{2}\right)$

\begin{tabular}{llll}
\hline$R$ & $R$ Square & Adjusted $R$ Square \\
\hline & $.532^{\mathrm{a}}$ & .283 & .209 \\
\hline
\end{tabular}

Sumber: data olahan

Tabel 6 hasil perhitungan koefisien determinasi pada analisis regresi linear berganda diperoleh nilia Adjusted R Square sebesar 0,209. Hal ini menunjukkan bahwa variabel Keterlibatan Pemakai, Kemampuan Teknik Personal, Dukungan Manajemen Puncak, Formalisasi Pengembangan dan Program Pelatihan dan Pendidikan Pemakai terhadap Kinerja Sistem informasi Akuntansi mampu menjelaskan variasi dari variabel dependen yaitu tingkat akrual sebesar 20,9\% sedangkan sisanya yaitu79,1\% dijelaskan oleh faktor atau variabel lain diluar model.

\section{Hipotesis Uji F}

Tabel 7

Tabel Uji F

\begin{tabular}{cccc}
\hline Model & F & Sig. & Keterangan \\
\hline Regression Residual Total & & 3,860 & $.005^{\mathrm{a}} \mathrm{H}_{0}$ ditolak, $\mathrm{H}_{1}$ diterima \\
\hline Sumber: data olahan & &
\end{tabular}

Hasil perhitungan regresi diperoleh nilai $\mathrm{F}$ hitung sebesar 3,860 dengan nilai probabilitas $0,005(\mathrm{p}<0,05)$ sehingga dapat disimpulkan bahwa model penelitian ini adalah fit. Hal ini menunjukkan bahwa seluruh variabel keterlibatan pemakai, kemampuan tehnik personal, dukungan manajemen puncak, formalisasi pengembangan dan program pelatihan dan pendidikan pemakai secara simultan mempunyai berpengaruh terhadap kinerja Sistem Informasi Akuntansi.Sehingga model regresi dapat digunakan dalam penelitian ini.

\section{Hipotesis Uji t}

Tabel 8

Uji t

\begin{tabular}{crrl}
\hline Model & T tabel & T hitung & \\
\hline X1 & 2,00958 & 2.371 & Signifikan \\
X2 & 2,00958 & .638 & Tidak Signifikan \\
X3 & 2,00958 & .317 & Tidak Signifikan \\
X4 & 2,00958 & .648 & Tidak Signifikan \\
X5 & 2,00958 & 2.384 & Signifikan \\
\hline
\end{tabular}

Sumber: data olahan

Maka diperoleh uji-t sebagai berikut:

1. Hasil perhitungan menggunakan SPSS versi 26, variabel $X_{1}$ diperoleh hasil $t_{\text {hitung }}>t_{\text {tabel }}(2,371>2,00958)$ dengan nilai signifikan $0,022<0,05$ yang artinya Ho ditolak, maka menunjukkan bahwa variabel $\mathrm{X}_{1}$ berpengaruh positif dan signifikan terhadap variabelY.

2. Hasil perhitungan menggunakan SPSS versi 26 , variabel $X_{2}$ diperoleh hasil $t_{\text {hitung }}>t_{\text {tabel }}(0,638<2,00958)$ dengan nilai signifikan 0,527>0,05 yang artinya Ho diterima, maka menunjukkan bahwa variabel $\mathrm{X}_{2 \mathrm{r}}$ tidak berpengaruh terhadap variabelY.

3. Hasil perhitungan menggunakan SPSS versi 26 , Variabel $X_{3}$ diperoleh hasil $t_{\text {hitung }}>t_{\text {tabel }}(0,317<2,00958)$ dengan nilai signifikan 0,752>0,05 yang artinya Ho diterima, maka menunjukkan bahwa variabel $\mathrm{X}_{3}$ tidak berpengaruh terhadap variabel $\mathrm{Y}$.

4. Hasil perhitungan menggunakan SPSS versi 26 , Variabel $X_{4}$ diperoleh hasil $t_{\text {hitung }}>t_{\text {tabel }}(0,648<2,00958)$ dengan nilai signifikan 0,520>0,05 yang artinya Ho diterima, maka menunjukkan bahwa variabel $\mathrm{X}_{4}$ tidak berpengaruh terhadap variabel Y

5. Hasil perhitungan menggunakan SPSS versi 26, variabel $X_{5}$ diperoleh hasil $t_{\text {hitung }}>t_{\text {tabel }}(2,384>2,00958)$ dengan nilai signifikan $0,021<0,05$ yang artinya Ho ditolak, maka menunjukkan bahwa variabel $\mathrm{X}_{5}$ berpengaruh positif dan signifikan terhadap variabel Y. 


\section{Pengaruh Keterlibatan Pemakai terhadap Kinerja Sistem InformasiAkuntansi.}

Hasil analisis data menunjukkan bahwa keterlibatan pemakai dalam proses pengembangan sistem informasi akuntansi (X1) memiliki tingkat signifikansi (sig t) sebesar 2,371 lebih besar dari $\square(=0,05)$. Berarti Hipotesis 1 diterima yang berarti secara parsial variabel keterlibatan pemakai perusahaan berpengaruh signifikan terhadap kinerja Sistem Informasi Akuntansi.Berdasarkan analisis tersebut dapat diperoleh kesimpulan bahwa hipotesis utama $\left(\mathrm{H}_{1}\right)$ diterima dan hipotesis nol $\left(\mathrm{H}_{0}\right)$ ditolak, yang artinya variabel keterlibatan pemakai dalam pengembangan sistem informasi akuntansi berpengaruh terhadap kinerja sistem informasi akuntansi.Keterlibatan pemakai dalam pengembangan sistem informasi akuntansi berpengaruh terhadap kinerja sistem informasi akuntansi karena dalam kinerja Sistem Informasi Akuntansi keterlibatan pemakai dalam pengembangan sistem sangat terbatas.Hal itu dikarenakan dalam sistem informasi, keterlibatan pemakai disesuaikan dengan bagian masing-masing dan sistem informasi yang digunakan karyawan tidak boleh digunakan sembarangan oleh setiap karyawan karena berisikan informasi-informasi yang bisa bersifat rahasia dalam perusahaan. Oleh karena itu, apabila karyawan mudah untuk menggunakan sistem dan terlibat semua dapat meningkatkan kinerja SIA karena sistem informasi akan lebih mudah diketahui oleh karyawan yang memiliki kepentingan. Pemberian informasi seharusnya dilakukan oleh karyawan sesuai dengan deskripsi masing-masing pekerjaannya atau diberikan oleh pemakai yang benar-benar memiliki wewenang untuk mengakses informasi tersebut.

\section{Pengaruh Kemampuan Teknik Personal Terhadap Kinerja Sistem Informasi Akuntansi.}

Hipotesis 2 menyatakan bahwa terdapat pengaruh antara variabel kemampuan teknik personal sistem informasi akuntansi terhadap kinerja sistem informasi akuntansi.Berdasarkan Tabel 4.6 menunjukkan bahwa kemampuan teknik personal sistem informasi akuntansi memiliki tingkat signifikansi (sig t) sebesar 0,638. Nilai ini lebih kecil (kurang) dari $\square(=0,05)$, maka Ho ditolak yang berarti secara parsial variabel kemampuan teknik personal sistem informasi akuntansi berpengaruh secara signifikan terhadap kinerja Sistem Informasi Akuntansi. Berdasarkan analisis tersebut dapat diperoleh kesimpulan bahwa hipotesis kedua $\left(\mathrm{H}_{2}\right)$ diterima dan hipotesis nol $\left(\mathrm{H}_{0}\right)$ ditolak, yang artinya variabel kemampuan teknik personal sistem informasi akuntansi berpengaruh terhadap kinerja sistem informasi akuntansi.

Kemampuan teknik personal sistem informasi akuntansi berpengaruh terhadap kinerja sistem informasi akuntansi. Hal ini menunjukkan bahwa karyawan yang menggunakan sistem informasi harus memiliki kemampuan yang sesuai dengan sistem informasi yang digunakan oleh karyawan.Pemakai sistem informasi akuntansi diharuskan memiliki kemampuan dan skill tentang komputer dan sistem informasi yang digunakan agar dapat melancarkan dan meningkatkan kinerja sistem informasi.

\section{Pengaruh Antara Dukungan Manajemen Puncak Terhadap Kinerja Sistem Informasi Akuntansi.}

Hipotesis 3 menyatakan bahwa terdapat pengaruh antara variabel dukungan manajemen puncak dalam proses pengembangan dan pengoperasian Sistem Informasi Akuntansi terhadap kinerja sistem informasi akuntansi. Dukungan manajemen puncak memiliki tingkat signifikansi (sig t) sebesar 0,317. Nilai ini lebih kecil (kurang) dari $\square$ $(=0,05)$, maka $\mathrm{H}_{3}$ ditolak yang berarti secara parsial variabel dukungan manajemen puncak berpengaruh secara signifikan terhadap kinerja Sistem Informasi Akuntansi. Berdasarkan hasil analisis tersebut dapat diperoleh kesimpulan bahwa hipotesis utama $\mathrm{H}_{3}$ ditolak dan $\mathrm{H}$ nol $\left(\mathrm{H}_{0}\right)$ diterima, yang artinya variabel pengaruh dukungan manajemen puncak tidak berpengaruh terhadap kinerja sistem informasi akuntansi.

\section{Pengaruh Antara Formalisasi Pengembangan Sistem Informasi Terhadap Kinerja Sistem Informasi Akuntansi.}

Hipotesis 4 menyatakan bahwa terdapat pengaruh antara formalisasi pengembangan sistem informasi terhadap kinerja sistem informasi akuntansi.Berdasarkan Tabel 4.6 menunjukkan bahwa program formalisasi pengembangan sistem informasi memiliki tingkat signifikansi (sig t) sebesar 0,648. Nilai ini lebih kecil (kurang) dari $\square(=0,05$ ), maka Ho dierima yang berarti secara parsial variabel formalisasi pengembangan sistem informasi tidak berpengaruh signifikan terhadap kinerja Sistem Informasi Akuntansi.

Formalisasi pengembangan sistem informasi berpengaruh signifikan terhadap kinerja sistem informasi akuntansi.Hal ini dikarenakan karena formulasi pengembangan sistem yang dilakukan secara periodik berhubungan dengan kinerja sistem informasi karena kenaikan kinerja sistem informasi lebih cenderung dari operasional sistem informasi dalam memperlancar pekerjaan yang membutuhkan informasi secara cepat dan tepat.

\section{Pengaruh Antara Program Pelatihan Dan Pendidikan Pemakai Terhadap Kinerja Sistem InformasiAkuntansi.}

Hipotesis 5 menyatakan bahwa terdapat pengaruh antara program pelatihan dan pendidikan pemakai terhadap kinerja sistem informasi akuntansi.Berdasarkan Tabel 4.6 menunjukkan bahwa program pelatihan dan pendidikan pemakai memiliki tingkat signifikansi (sig t) sebesar 2,384. Nilai ini lebih besar dari $\square(=0,05)$, maka Ho ditolak yang berarti secara parsial variabel program pelatihan dan pendidikan pemakai berpengaruh signifikan terhadap kinerja Sistem Informasi Akuntansi Berdasarkan analisis tersebut dapat diperoleh kesimpulan bahwa hipotesis kelima 
Annisa' Amanatyas Wahyudi Putri*, Endang Masitoh dan Purnama Siddi, Analisis Faktor-Faktor Yang Mempengaruhi Kinerja Sistem Informasi Akuntansi (Studi Empiris Pada Boys Bakery and Cake Sukoharjo)

$\left(\mathrm{H}_{5}\right)$ diterima dan hipotesis nol $\left(\mathrm{H}_{0}\right)$ ditolak, yang artinya variabel program pelatihan dan pendidikan berpengaruh positif dan signifikan terhadap kinerja sistem informasi akuntansi.

\section{SIMPULAN}

Berdasarkan hasil penelitian dan pembahasan tentang Analisis dapat ditarik kesimpulan bahwa:

1. Keterlibatan pemakai dalam pengembangan sistem informasi berpengaruh terhadap kinerja sistem informasi akuntansi Boys Bakery and Cake Sukoharjo Tahun 2020

2. Kemampuan teknik personal sistem informasi akuntansi tidak berpengaruh terhadap kinerja sistem informasi akuntansi Boys Bakery and Cake Sukoharjo Tahun 2020

3. Dukungan manajemen puncak tidak berpengaruh terhadap kinerja sistem informasi akuntansi Boys Bakery and Cake Sukoharjo Tahun 2020

4. Formalisasi pengembangan sistem informasi tidak berpengaruh terhadap kinerja sistem informasi akuntansi Boys Bakery and Cake Sukoharjo Tahun 2020

5. Program pelatihan dan pendidikan pemakai berpengaruh terhadap kinerja sistem informasi akuntansi Boys Bakery and Cake Sukoharjo Tahun 2020

\section{DAFTAR PUSTAKA}

Acep, Komara. 2005. Analisis Faktor-Faktor Yang Mempengaruhi Kinerja Sistem Informasi Akuntansi. Surakarta: Simposium Nasional Akuntansi VIII 15-16 September.

Almilia, LS dan Irmaya Briliantien, 2007. Faktor-faktor yang Mempengaruhi Kinerja Sistem Informasi Akuntansi pada Bank Umum Pemerintah di Wilayah Surabaya dan Sidoarjo. Jurnal Akuntansi. Surabaya: STIE Perbananas.

Ghozali, Imam. 2016. Aplikasi Analisis Multivariete Dengan Program IBM SPSS 23 (Edisi 8). Cetakan ke VIII. Semarang: Badan Penerbit Universitas Diponegoro.

Mulyadi. (2016). Sistem Akuntansi. Jakarta: Penerbit Salemba Empat.

Rusdi Dedi, Megawati Nurul. 2011. "Analisis Faktor-faktor yang mempengaruhi Informasi Akuntansi (SIA)". Jurnal Majalah Ilmiah Agung 2. Vol. 49 No. 125

Sugiyono. 2013. Metode Penelitian Pendidikan Pendekatan Kuantitatif, Kualitatif dan R\&D. (Bandung: Alfabeta, 2013), h. 61.

Susanto, Azhar. (2013). Sistem Informasi Akuntansi edisi pertama. Bandung: Lingga Jaya 